ISSN: 2338-4328 (Print), ISSN: 2686-2646 (Online)

Available online at: https: sultanist.ac.id/index.php/sultanist

\title{
ANALISIS PERBANDINGAN UKURAN PERUSAHAN ANTARA PT TELKOMSEL TBK DAN PT XL AXIATA TBK
}

\author{
Ahlul Nazar'), Nurul Huda ${ }^{2)}$ \\ Program Studi Manajemen, Sekolah Tinggi Ilmu Ekonomi (STIE) Bima, \\ lparce20@gmail.com \\ Program Studi Manajemen, Sekolah Tinggi Ilmu Ekonomi (STIE) Bima, \\ Nurulhuda.stiebima@gmail.com
}

\begin{abstract}
Abstrak
Penelitian ini bertujuan untuk mengetahui seberapa besar perbedaan yang signifikan ukuran perusahaan antara PT Telkomsel Tbk dan PT XL Axiata Tbk. Penelitian komparatif, populasi penelitian ini adalah data laporan keuangan PT Telkomsel Tbk selama 22 tahun dari tahun 1997-2018 dan PT XI Axiata Tbk yaitu selama 18 tahun dari tahun 1999-2018. Teknik pengambilan sampel dalam penelitian ini menggunakan Purposive Sampling. Sampel penelitian ini selama 5 tahun dari 2014-2018 terdaftar di bursa saham. Jenis data penelitian kuantitatif dengan sumber data sekunder. Teknik analisis data menggunakan uji normalitas data dan independent sample ttest. Analisis menunjukkan bahwa variabel Ukuran Perusahan pada PT Telkomsel Tbk dan PT XL Axiata Tbk. berdasarkan nilai Sig (2-tailed) sebesar 0,010 sehingga nilai signifikan 0,000>0, 05, maka Ha ditolak dan H0 diterima yang menyatakan bahwatidak ada perbedaan yang signifikan antara Ukuran Perusahaanpada PT Telkomsel Tbk dan PT XL Axiata Tbk.
\end{abstract}

Kata Kunci :Ukuran Perusahaan, PT Telkomsel Tbk, PT XL AxiataTbk

\section{COMPARATIVE ANALYSIS OF COMPANY SIZES BETWEEN PT TELKOMSEL TBK AND PT XL AXIATA TBK}

\begin{abstract}
This study aims to find out how big a significant difference in company size between PT Telkomsel Tbk and PT XL Axiata Tbk. Comparative research, the population of this study is the data of PT Telkomsel Tbk financial statements for 22 years from 1997-2018 and PT Xl Axiata Tbk for 18 years from 1999-2018. The sampling technique in this study uses purposive sampling. This research sample for 5 years from 2014-2018 was listed on the stock exchange. Types of quantitative research data with secondary data sources. The data analysis technique uses normality test data and independent sample t-test. The analysis shows that the Company Size variable at PT Telkomsel Tbk and PT XL Axiata Tbk. based on the Sig (2-tailed) value of 0.010 so that a significant value of $0,000>0,05, \mathrm{Ha}$ is rejected and $\mathrm{HO}$ is accepted stating that there is no significant difference between Company Size at PT Telkomsel Tbk and PT XL Axiata Tbk.
\end{abstract}

Keywords: Company Size, PT Telkomsel Tbk, PT XL Axiata Tbk

Article History: Received: 08 April 2020 Revised: 25 April 2020 Accepted: 23 Mei 2020

Copyright (C) 2020, SULTANIST: Jurnal Manajemen dan Keuangan 


\section{PENDAHULUAN}

Dalam era globalisasi, komunikasi memegang peranan yang sangat penting sebagai media penghubung yang semakin tidak dapat dibatasi oleh ruang dan waktu. Hubungan komunikasi yang semakin mengglobal ini tidak hanya terbatas pada bentuk komunikasi suara saja, akan tetapi merambah ke komunikasi dalam bentuk data ataupun bentuk visual lainnya. Peran jasa telekomunikasi dewasa ini semakin nyata dalam mendorong pertumbuhan ekonomi nasional dan oleh pemerintah peran tersebut dimasa mendatang diharapkan dapat semakin besar lagi.

Ukuran perusahaan secara umum dapat diartikan sebagai suatu perbandingan besar atau kecilnya suatu objek. Ukuran perusahaan adalah suatu skala dimana dapat diklasifikasikan besar kecilnya perusahaan menurut berbagai cara, antara lain: total aktiva, nilai pasar saham, jumlah karyawan, dan lain- lain. Menurut I Gusti Ngurah Gede Rudangga dan Gede Merta Sudiarta (2016 ): "Ukuran perusahaan dapat dinyatakan dengan total asset yang di miliki oleh perusahaan. Dalam ukuran perusahaan terdapat tiga variabel yang dapat menentukan ukuran perusahaan yaitu total asset, penjualan, dan kapitalisasi pasar dikarenakan variabel itu dapat menentukan besarnya suatu perusahaan".

Adnan dan Kurniasih (2011) menyatakan bahwa ukuran perusahaan atau insolvensi ukuran diartikan sebagai laporan keuangan atau financial failure

kuran suatu perusahaan adalah analisis perbandingan yang dikembangkan oleh Altman dkk Ukuran perusahaan merupakan cerminan total dari aset yang dimiliki suatu perusahaan. Ukuran perusahaan salah satunya dapat diukur dengan total aktiva, Ukuran perusahaan dianggap mampu mempengaruhi nilai perusahaan karena semakin besar ukuran suatu perusahaan maka akan semakin mudah perusahaan tersebut mendapatkan sumber pendanaan.

PT. Telkomsel tbk merupakan perusahaan telekomunikasi yang menghasilkan produk pra bayar meliputi kartu simPATI dan Kartu AS, sedangkan PT. XLAxiata tbk, perusahaan yang menghasilkan produk meliputi kartu AXIS dengan bersaing untuk tetap saling mempertahankan pangsa pasarnya sebagai operator perusahaan telekomunikasi yang berkualitas, menjamin kepuasan masyarakat yang memakainya dan tetap diminati masyarakat. PT.XL Axiata tbk merupakan perusahaan telekomunikasi yang mengalami penurunan ukuran perusahaan pada tahun 2016 di bandingkan dengan PT. Telkomsel, dengan ukuran perusahaan pada tingkat volume penjualan yang mencapai angka 4500 unit, sedangkan PT XLAxiata tbk dengan tingkat volume penjualan hanya 3000 unit.

PT Telkomsel tbk dan PT XL Axiata tbk dalam meningkatkan ukuran perusahaan harus dapat menemukan inovasi dan modusmodus baru guna menjawab tantangan kreasi pelayanan jasa di dunia seluler yang tumbuh dinamis. Disamping harus menghadapi pesaing yaitu operator telepon seluler yang mempergunakan teknologi telekomunikasi yang mempunyai kegunaan yang sama.

PT Telkomsel tbk dan PT XLAxaita tbk harus mampu menghadapi pesaing. Pada tahun 2012, Operator yang memiliki jumlah pelanggan pengguna kartu prabayar terbesar adalah PT Telkomsel yaitu sebanyak : 79.608 .839 serta tumbuh $6 \%$ menjadi Rp 17,83 Triliun dengan $78 \%$ diperoleh dari produk Simpati Untuk tetap meningkatkan pangsa pasar kartu prabayar dari PT Telkomsel tbk, perusahaan diharuskan dapat membangun suatu sistem yang terus bisa mempertahankan penjualan dan loyalitas dari pelanggan. Sehingga diperlukan suatu sistem yang tepat yang dapat menentukan suatu kebijakan pengambilan keputusan perusahaan. Kemudian dari tahun 2012 sampai dengan tahun 2016 ini GSM semakin berkembang dengan dua operator simPATI dan AS yang berlisensi nasional yaitu Telkomsel dengan jumlah pelanggan 81,644 juta. 
PT XLAxiata tbk dengan jumlah pelanggan 31,437 juta, pada akhir tahun 2016 dengan nilai penjualan sebesar = $23,5 \%$ untuk tetap meningkatkan penjualanya, maka di butuhkan langkahlangkah yang strategis dalam menghadapi pesaing yang sama bergerak di bidang telekomunikasi. PT XLAxiata tbk. Untuk mencapai hal tersebut diperlukan konsep dan pelaksanaan bauran pemasaran yang komprehensif yang tercakup didalamnya konsep promosi.

Berdasarkan uraian diatas maka peneliti tertarik untuk melakukan penelitian dengan judul Analisis Perbandingan Ukuran Perusahan pada PT Telkomsel Tbk Dan PT XL Axiata Tbk. Rumusan masalah dalam penelitian ini adalah Seberapa besar perbedaan yang signifikan Ukuran Perusahaan antara PT Telkomsel Tbk Dan PT XL Axiata Tbk.? Tujuan penelitian ini adalah untuk mengetahui seberapa besar perbedaan yang signifikan Ukuran Perusahaan antara PT Telkomsel Tbk Dan PT XL Axiata Tbk. Batasan ruang lingkup dari penelitian yang akan dilakukan. Peneliti hanya membatasi permasalahan pada Ukuran Perusahaan antara PT Telkomsel Tbk Dan PT XL Axiata Tbk. Dalam penelitian ini peneliti ingin mengetahui seberapa besar perbedaan yang signifikan Ukuran Perusahaan antara PT Telkomsel Tbk Dan PT XL Axiata Tbk

\section{LANDASAN TEORI}

\section{Ukuran Perusahaan}

Menurut Sujoko dan Soebiantoro (2007) dalam Sulistiono (2010), ukuran perusahaan merupakan cerminan besar kecilnya perusahaan yang nampak dalam nilai total aktiva perusahaan pada neraca akhir tahun. Dalam Situmorang (2017), dijelaskan bahwa ukuran perusahaan adalah suatu skala di mana dapat diklasifikasikan besar kecil perusahaan menurut berbagai cara, antara lain: total aktiva, log size, nilai pasar saham, dan lain-lain.

Menurut Brigham dan Houston (2001) dalam Pratiwi (2016), ukuran perusahaan adalah rata-rata total penjualan bersih untuk tahun yang bersangkutan sampai beberapa tahun kemudian. Dalam hal ini penjualan lebih besar daripada biaya variabel dan biaya tetap, maka akan diperoleh jumlah pendapatan sebelum pajak. Sebaliknya, jika penjualan lebih kecil dari pada biaya variabel dan tetap maka perusahaan akan menderita kerugian.

Berdasarkan uraian tentang pengertian ukuran perusahaan di atas, maka dapat disimpulkan bahwa ukuran perusahaan merupakan suatu indikator yang dapat menunjukkan kondisi atau karakteristik suatu organisasi atau perusahaan di mana terdapat beberapa parameter yang dapat digunakan untuk menentukan ukuran besar/kecilnya suatu perusahaan, seperti total aktiva yang dimiliki perusahaan, total penjualan yang dicapai oleh perusahaan dalam suatu periode, log size, serta jumlah saham yang beredar.

\section{Indikator Ukuran Perusahaan}

Menurut keputusan ketua BAPEPAM No. IX.C.7, indikator yang biasa digunakan dalam menentukan ukuran perusahaan adalah :

\section{Tenaga Kerja}

Merupakan jumlah pegawai tetap dan kontraktor yang terdaftar atau bekerja di perusahaan pada suatu saat tertentu.

\section{Tingkat Penjualan}

Merupakan volume penjualan suatu perusahaan pada suatu periode tertentu misalnya satu tahun.

3.Total Utang Ditambah Dengan Nilai Pasar Saham Biasa

Merupakan jumlah utang dan nilai pasar saham biasa perusahaan pada suatu tanggal tertentu.

\section{Total Aset}

Merupakan keseluruhan aktiva yang dimiliki perusahaan pada periode tertentu. Berdasarkan sub-sub penjelasan di atas, maka ukuran perusahaan dapat diinterpretasikan sebagai pengukur yang menunjukkan besar kecilnya sebuah perusahaan. Ukuran perusahaan diukur berdasarkan jumlah tenaga kerja, tingkat penjualan, total hutang, nilai pasar saham, dan total aset. 


\section{Pengukuran Ukuran Perusahaan}

Untuk mengukur ukuran perusahaan dalam penelitian ini, maka salah satu indikator yang digunakan adalah total aktiva agar lebih fokus dan hasil yang dicapai sesuai dengan asumsi yang diharapkan. Di mana total aktiva tersebut diukur dengan Logaritma Natural (Ln) dari total aktiva. Hal ini dikarenakan total aktiva perusahaan bernilai besar dan untuk menghindari adanya data yang tidak normal, maka total aktiva dapat disederhanakan dengan mentransformasikannya ke dalam Logaritma Natural, tanpa mengubah proporsi dari nilai asal yang sebenarnya. Logaritma Natural sendiri adalah logaritma yang berbasis e yaitu 2,7182818 yang terdefinisikan untuk semua bilangan real positif $\mathrm{x}$ dan dapat juga didefinisikan untuk bilangan kompleks yang bukan nol. Menurut Damayanti (2016), indikator penilaian ukuran perusahaan dapat digunakan rumus sebagai berikut :

$$
\text { Size }=\text { Ln }(\text { Total Aktiva) }
$$

Keterangan :

$$
\begin{array}{lll}
\text { Size } & = & \text { Ukuran Perusahaan } \\
\text { Ln } & = & \text { Logaritma Natural }
\end{array}
$$

Sumber : Damayanti (2016)

\section{Penelitian Terdahulu}

Penelitian tentang capital adequacy ratio telah dilakukan oleh para peneliti sebelumnya, namun menunjukan hasil yang berbeda-beda. Beberapa penelitian tersebut adalah :

Tisna Amijaya , (2014) tentang "Pengaruh profitabilitas, leverage, dan ukuran perusahan terhadap nilai perusahan (Studi pada Perusahaan Manufaktur Sub Sektor Barang dan Konsumsi yang Terdaftar di Bursa Efek Indonesia Periode 2012-2015)" adapun variabel dalam penelitian ini adalah Profitabilitas (X1), leverage (X2), Ukuran Perusahaan (X3) dan nilai perusahaan (Y). Dengan menggunakan teknik analisis data "analisis statistik deskriptif dan analisis regresi data panel"
Yangs Analisa, (2011) dengan judul penelitian "analisis pengaruh Corporate governance, ukuran perusahaan, dan leverage Terhadap manajemen laba perusahaan manufaktur indonesia". Adapun variabel dalam peneliltian ini adalah Corporate Governance (X1), Ukuran Perusahaan (X2), Leverage (X3), dan manajemen laba perusahaan (Y).

\section{Kerangka Pikir}

Berdasarkan uraian diatas, maka untuk lebih mengarahkan ketepatan penelitian saya sebagai peneliti membuat rangkaian kerangka pikir penelitian sebagai berikut :

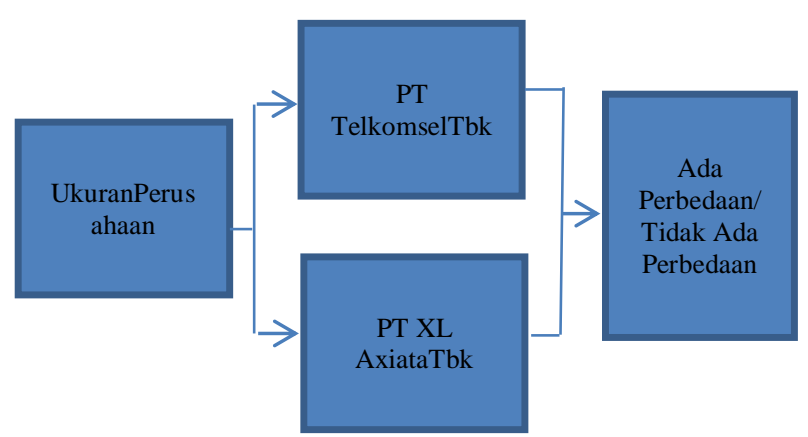

Gambar 1. Kerangka Pikir

\section{Hipotesis}

$\mathrm{H} 0: \mu_{1}=\mu_{2} \quad$ Tidak ada perbedaan yang signifikan Ukuran Perusahaan antara PT Telkomsel Tbk dan PT XL Axiata Tbk

Ha $: \mu_{1} \neq \mu_{2} \quad$ Ada perbedaan yang signifikan Ukuran Perusahaan antara PT Telkomsel Tbk dan PT XL Axiata Tbk.

\section{METODE}

\section{Jenis Penelitian}

Adapun jenis penelitian ini adalah komparatif yaitu suatu penelitian yang bersifat membandingkan (Sugiyono, 2003). Maksud penulis menggunakan metode penelitian komparatif adalah untuk mengetahui seberapa besar perbedaan yang signifikan Perbandingan Ukuran Perusahan pada PT Telkomsel Tbk Dan PT XL Axiata Tbk. dengan cara membandingkan. 


\section{Instrument Penelitian}

Populasi dalam penelitian ini adalah laporan keuangan bentuk laporan neraca pada PT. Telkomsel Tbk dan PT. Xl Axiata Tbk selama 21 tahun yaitu mulai dari tahun 1997 - 2018. Sampel adalah bagian dari jumlah dan karakteristik yang dimiliki oleh populasi tersebut. (Sugiyono, 2012:81). Sampel dalam penelitian ini adalah laporan pada PT. Telkomsel Tbk dan PT. Xl Axiata Tbk dalam bentuk laporan neraca selama 5 (lima) tahun dari tahun 2014 sampai tahun 2018 .

\section{Teknik pengambilan sampel}

Sampling yang digunakan yaitu sampling purposive .Menurut Sugiyono (2012:85) Sampling Purposive adalah teknik penentuan sampel dengan pertimbangan tertentu. Adapun pertimbangan yang dilakukan penulis adalah terletak pada ketersediaan data dan penggunaan data yang masih baru (update).

\section{Lokasi Penelitian}

Penelitianini dilakukan pada PT Telkomse Tbkl dan PT XL Axiata Tbk Jl. Jend. Gatot Subroto Kav. 52Jakarta Selatan 12710 dan PT XL Axiata Tbk beralamat Jl. Mega Kuningan Lot. E4-7 No. 1 Kawasan Mega KuninganJakarta 12950. Penelitian dilaksanakan selama 4 bulan yaitu dari bulan Oktober 2019 sampai januari 2020.

\section{Teknik Pengumpulan Data}

Teknik pengumpulan data yang digunakan penulis dalam penelitian ini adalah dokumentasi yaitu mencari data mengenai hal-hal atau variabel yang berkaitan dengan penelitian yang dibahas berupa catatan, transkrip, buku, jurnal-jurnal terdahulu dan sebagainya. Didalam melaksanakan metode dokumentasi ini, peneliti mengumpulkan data dokumentasi berupa laporan keuangan PT. Telkomsel Tbk dan PT. Xl Axiata Tbk Periode tahun 2014 - 2018. Selain itu teknik pengumpulan data yang digunakan berupa studi pustaka, yaitu dilakukan dengan cara mempelajari literatur-literatur serta pendapat para ahli yang ada relevansi dengan judul penelitian ini. Adapun jenis data yang digunakan dalam penelitian ini adalah data kuantitatif berupa laporan keuangan PT. Telkomsel Tbk dan PT. Xl Axiata Tbk selama 5 (lima) tahun yaitu dari tahun 2014 sampai dengan tahun 2018. Dalam penelitian ini sumber data yang digunakan adalah data sekunder yang diperoleh dari Data laporan keuangan per 31 Desember (Tahunan) PT. Telkomsel Tbk tahun 2014-2018 dan PT. XL Axiata Tbk tahun 2014-2018.

\section{Tehnik analisa data}

Hipotesis dalam uji beda dua rata-rata Independent sample t-test (Uji t)dengan rumus yaitu:

$$
t=\frac{\overline{X_{1}}-\overline{X_{2}}}{\sqrt{\frac{\left(n_{1}-1\right) s_{1}{ }^{2}+\left(n_{2}-1\right) s_{2}{ }^{2}}{n_{1}+n_{2}-2}\left(\frac{1}{n_{1}}+\frac{1}{n_{2}}\right)}}
$$

dimana

$$
\begin{aligned}
& \overline{X_{1}}=\text { rata }- \text { rata sampel } 1 \\
& \overline{X_{2}}=\text { rata }- \text { rata sampel } 2 \\
& n_{1}=\text { jumlah sampel } 1 \\
& n_{2}=\text { jumlah sampel } 2 \\
& s_{1}=\text { simpangan baku sampel } 1 \\
& s_{2}=\text { simpangan baku sampel } 2
\end{aligned}
$$

\section{HASIL DAN PEMBAHASAN}

Berdasarkan hasil perhitungan dengan program SPSS for Windows versi 26.0 persamaan regresi linear sederhana sebagai berikut :

\section{Analisis pengujian hipotesis}

Tabel 2. Independent sample t-test

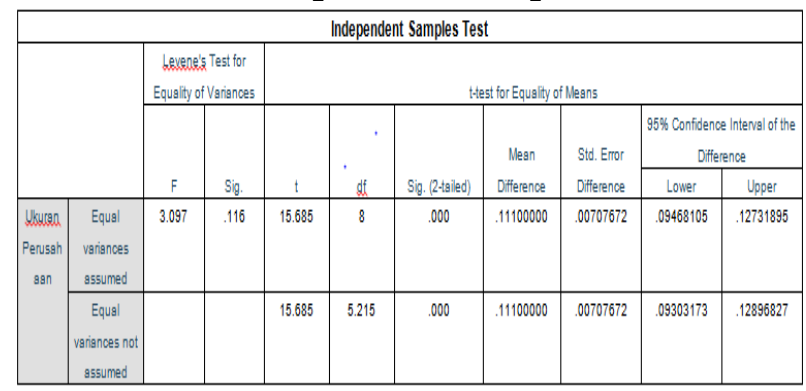

Sumber data : spss versi 26 (2020)

Berdasarkan tabel diatas nilai sig. Levene's Test for Equality of Variances adalah sebesar 0,116>0,05 maka dapat diartikan bahwa varian data antara PT Telkomsel Tbk dan PT XL Axiata adalah homogen atau sama (Sujarweni, 2014) 
Independen sampel Test pada bagian Equal varances assumed diketahui nilai sig. (2tailed) sebesar $0,000>0,05$, maka sebagai mana dasar pengambilan keputusan dalam uji independen sampel $t$ test dapat disimpulkan bahwa Ha ditolak dan Ho diterima. Dengan demikian dapat disimpukan bahwa tidak ada perbedaan yang signifikan (nyata) ukuran perusahaan antara PT Telkomsel Tbk dan PT XL Axiata. Dan diketahui nilai "Mean Difference" adalah sebesar 0.11100000 . Nilai ini menunjukan selisih antara Ukuran Perusahaan pada PT Telkomsel Tbk dan PT XL Axiata atau 2.5898000-2.4788000 = 0.111 dan selisih perbedaan tersebut adalah 0.09468105 sampai $0.12731895 \quad(95 \%$ Confidence Intl Of The Difference Lower Upper). Dengan demikian nilai $\mathrm{t}$ hitung adalah sebesar $15.685>\mathrm{t}$ tabel 3,182, maka berdasarkan dasar pengambilan keputusan melalui perbandingan nilai $t$ hitung dengan $t$ tabel, dapat disimpulkan bahwa H0 ditolak dan $\mathrm{Ha}$ diterima, yang berarti untuk mengetahui seberapa besar perbedaan yang signifikan ukuran perusahaan PT. Telkomsel Tbk dan PT. Xl Axiata Tbk .

\section{KESIMPULAN DAN SARAN}

\section{Kesimpulan}

Berdasarkan hasil penelitian dan analisis data yang dilakukan maka penulis menarik kesimpulan bahwa ada perbedaan yang signifikan Ukuran Perusahaan yang nyata dari kedua varian, yang mana penggunaan varian untuk membandingkan rata-rata populasi dengan uji-t menggunakan Equal Varience not Assumed (karena data homogen/ memiliki varian sama). Maka hasil hipotesisnya adalah menerima Ha yang menyatakan bahwa terdapat perbedaan yang signifikan ukuran perusahaan antara PT. Telkomsel Tbk dan PT. Xl Axiata Tbk

\section{Saran}

Berdasarkan kesimpulan yang telah dikemukakan diatas, maka penulis memberikan saran yang dapat dijadikan saran masukan bagi peneliti, perusahaan PT.
Telkomsel Tbk dan PT. Xl Axiata Tbk. Bagi perusahaan: perusahaan diharapkan dapat mempertahankan dan meningkatkan jumlah modalnya agar tetap sesuai dengan ketentuan yang berlaku. Bagi peneliti: penelitian ini dapat menjadi referensi untuk melakukan penelitian lain yang berkaitan dengan Ukuran Perusahaan ataupun penelitian yang sama dengan menambahkan variabel penelitian yang berkaitan dengan kinerja keuangan perbankan. Penelitian selanjutnya sebaiknya menggunakan.

\section{DAFTAR PUSTAKA}

Riyanto, (2008). Pengaruh ukuran perusahaan, leverage,profitabilitas dan kebijakan dividenterhadap nilai perusahan.

Soraya, (2012). Pengaruh struktur modal, profitabilitas dan ukuran perusahaan pada nilai perusahaan. E-jurnal akuntansi universitas Udayana. ISSN : 2302-8556. Fakultasekonomi Universitas Udayana : Bali.

Fahmi, Irham. (2011). Analisis Laporan Keuanagan. Bandung: Alfabeta.

Adnan dan Kurniasih. 2002. Pengaruh Kebijakan Hutang Terhadap Nilai Perusahaan Serta Beberapa Faktor Yang Mempengaruhinya. Dalam Jurnal Bisnis dan Ekonomi.

Sugiyono. 2011. Metode Penelitian Bisnis. Alfabeta, CV : Bandung.

Weston dan Copelan. 2006. Studi Empiris Terhadap Faktor yang Mempengaruhi Nilai Perusahaan pada Perusahaan Go Public di Indonesia. Dalam Jurnal Manjemen Akuntansi, 6(1): h: 23-24.

Susanti, Rika. 2010. Analisis Faktor-Faktor yang Berpengaruh Terhadap Nilai Perusahaan. Skripsi FPeraturan Menteri Komunikasi dan Informatika Nomor:

01/PER/M.KOMINFO/01/2010 tentang Penyelenggaraan Jaringan Telekomunikasi, Kementrian Konunikasi dan Informatika Republik Indonesia (2010). 
Sawir, (2004) Statistik Bidang Pos dan Telekomunikasi, Jakarta: Direktorat Jenderal POS dan Telekomunikasi (2009). Jumlah dan pertumbuhan pelanggan telekomunikasi dalam menggunakan kartu prabayar, Direktorat Jenderal Sumber Daya dan Perangkat Pos dan Informatika (2011).

www.telkomsel indonesia.com di unduh pada tgl 20 desember 2019 www. xlaxiata indonesia.com, di unduh pada tgl 20 desember 2019.

\section{PROFIL SINGKAT}

Ahlul Nazar, sangat kagum dipanggil dengan Ahlul. Lahir 1995 tepat tanggal 6 april di Kota Bima, NTB. Hobi music tapi berkerja di bidang elektronik dan bercitacita menciptakan teknologi canggih yang berguna untuk semua orang. Sampai saat ini saya masih menjadi mahasiswa di Sekolah Tinggi Ilmu Ekonomi Bima. 